\title{
PENGARUH PEMBELAJARAN KEWIRAUSAHAN MELALUI BUSINESS CENTER, PRAKERIN, DAN LATAR BELAKANG KELUARGA TERHADAP KOMPETENSI BERWIRAUSAHA
}

\author{
Ertyn Tyas Prabandari \\ SMK BOPKRI 1 Yogyakarta \\ Ertyn_14@yahoo.com \\ Aliyah A. Rasyid \\ Universitas Negeri Yogyakarta \\ Aliyahrasyid@gmail.com
}

\begin{abstract}
Abstrak
Penelitian ini bertujuan untuk mengetahui pengaruh: (1) pembelajaran kewirausahaan melalui business center, (2) prakerin, (3) latar belakang keluarga, dan (4) pembelajaran kewirausahaan melalui business center, prakerin, dan latar belakang keluarga secara bersama-sama terhadap kompetensi berwirausaha. Penelitian ini adalah penelitian asosiatif kausal. Populasi penelitian ini adalah seluruh siswa kelas XI SMK Negeri kelompok bismen di Kota Yogyakarta. Sampel sebanyak 221 siswa ditentukan menggunakan teknik random sampling. Teknik pengumpulan data menggunakan dokumentasi dan angket. Data variabel dianalisis dengan statistik deskriptif. Pengaruh setiap variabel bebas terhadap variabel terikat dianalisis dengan statistik regresi sederhana dan regresi berganda. Hasil penelitian ini menunjukkan bahwa: (1) pembelajaran kewirausahaan melalui business center berpengaruh positif dan signifikan terhadap kompetensi berwirausaha siswa SMK $(0,000<0,05)$; (2) prakerin berpengaruh positif dan signifikan terhadap kompetensi berwirausaha siswa SMK $(0,000<0,05)$; (3) latar belakang keluarga berpengaruh positif dan signifikan terhadap kompetensi berwirausaha siswa SMK $(0,000<0,05)$; (4) pembelajaran kewirausahaan melalui business center, prakerin, dan latar belakang keluarga secara besama-sama berpengaruh positif dan signifikan terhadap kompetensi berwirausaha siswa $\operatorname{SMK}(0,000<0,05)$.
\end{abstract}

Kata Kunci: business center, prakerin, latar belakang keluarga, kompetensi berwirausaha

\section{THE EFFECT OF ENTREPRENEURSHIP TEACHING THROUGH A BUSINESS CENTRE, PRATICAL WORK, AND FAMILY BACKGROUND ON THE ENTREPRENEURSHIP COMPETENCE}

\begin{abstract}
This research is aimed to reveal the effect of: (1) entrepreneurship teaching through business centre; (2) practical work; (3) family background; (4) entrepreneurship teaching through a business centre, practical work, and family background on the entrepreneurship competence. This is an associative causal research. The population was all graduate XI students of state vocational high school of business and management group in Yogyakarta City. A sample of 221 students was established using the proportional random sampling technique. The data were collected through documentation and questionnaire. The variable data were analyzed using the descriptive statistics. The effect of each independent variable on the dependent variable was analyzed using the simple and multiple regression statistics. The result of the research shows that: (1) entrepreneurship teaching through business centre gives a positive and significant effect on vocational high school students'entrepreneurship competence $(0.000<0.05)$; (2) practical work gives a positive and significant effect on vocational high school students' entrepreneurship competence $(0.000<0.05)$; (3) family background gives a positive and significant effect on vocational high school students'entrepreneurship competence $(0.000<0.05)$; (4) entrepreneurship teaching through business centre, practical work, and family background provide a positive and significant effect on vocational high school students' entrepreneurship competence $(0.000<0.05)$.
\end{abstract}

Keywords: business centre, practical work, family background, entrepreneurship competence 


\section{PENDAHULUAN}

UU No. 20 Tahun 2003 Tentang Sistem Pendidikan Nasional pada Pasal 3, menyatakan bahwa Pendidikan Nasional berfungsi mengembangkan kemampuan dan membentuk watak serta peradaban bangsa yang bermartabat dalam rangka mencerdaskan kehidupan bangsa. Sistem pendidikan Nasional bertujuan untuk mengembangkan potensi peserta didik agar menjadi manusia yang beriman dan bertakwa kepada Tuhan Yang Maha Esa, berakhlak mulia, sehat, berilmu, cakap, kreatif, mandiri, dan menjadi warga negara yang demokratis serta bertanggung jawab.

Sekolah Menengah Kejuruan (SMK) adalah salah satu bentuk satuan pendidikan formal yang menyelenggarakan pendidikan kejuruan pada jenjang pendidikan menengah sebagai lanjutan dari SMP, MTs, atau bentuk lain yang sederajat. Sebagai bagian dari Sistem Pendidikan Nasional, SMK merupakan pendidikan yang lebih mengutamakan pengembangan kemampuan peserta didik untuk dapat bekerja dalam bidang tertentu, kemampuan beradaptasi di lingkungan kerja, melihat peluang kerja dan mengembangkan diri di kemudian hari. Dengan kata lain bahwa SMK berperan dalam menyiapkan peserta didik agar siap bekerja, baik bekerja secara mandiri dengan berwirausaha maupun mengisi lowongan pekerjaan yang ada.

Deputi Bidang Restrukturisasi dan Pengembangan Usaha Kementerian Koperasi dan UKM, Chairul Djamhari menyebutkan, jumlah wirausaha di Indonesia hanya sekitar 1,25 persen masih jauh jika dibandingkan dengan negara tetangga seperti Malaysia mencapai 4 persen, Thailand 4,1 persen, dan Singapura 7,2 persen(Sindonews, 19 September 2013). Menurut Ketua Dewan Komisioner Diplomats Success Challenge (DSC) 2013 Surjanto Yasaputera saat peluncuran DSC 2013 di Jakarta agar bisa menggerakkan ekonomi nasional, jumlah wirausahawan minimal 2 persen (Pikiran Rakyat, 01 September 2013).

Hal tersebut senada dengan David Mc Clelland (1971: p.98) bahwa suatu negara dapat mencapai kemakmuran apabila memiliki jumlah entrepreneur (wirausaha) sebanyak $2 \%$ dari jumlah populasi penduduk negara tersebut.
Yohanes Surya menyatakan akan sangat ideal kalau suatu bangsa memiliki $10 \%$ orang yang berjiwa kewirausahaan karena merekalah yang mampu menjadi motor pertumbuhan ekonomi suatu bangsa (www.langkahwirausaha.com). Sehingga dapat disimpulkan bahwa kemajuan ekonomi suatu bangsa ditentukan oleh banyaknya orang yang memiliki semangat berwirausaha.

Kompetensi kewirausahaan merupakan karakteristik yang mendasar dari seseorang individu dalam menciptakan peluang atau kesempatan secara kreatif dan inovatif. Wirausaha yang sukses pada umumnya adalah mereka yang memiliki kompetensi dalam ilmu pengetahuan, keterampilan dan kualitas individu yang meliputi sikap, motivasi, nilai serta tingkah laku yang diperlukan untuk melaksanakan pekerjaan/kegiatan. Hal tersebut diperkuat dengan pernyataan Suryana (2008: p.4) bahwa seorang wirausaha tidak akan berhasil apabila tidak memiliki pengetahuan, kemampuan, dan kemauan.

Dalam mempersiapkan lulusan agar siap untuk bekerja, maka pada SMK dapat didirikan unit produksi yang beroperasi secara profesional. Keberadaan unit produksi di lingkungan SMK berfungsi sebagai (1) wahana pelatihan berbasis produksi bagi siswa; (2) wahana menumbuhkan dan mengembangkan jiwa wirausaha pada siswa SMK; (3) sarana praktik produktif secara langsung bagi siswa; (4) membantu pendanaan untuk pemeliharaan, penambahan fasilitas dan biaya-biaya operasional pendidikan lainnya; (5) menambah semangat kebersamaan, karena dapat menjadi wahana peningkat aktivitas produktif siswa serta memberi 'income' serta peningkatan kesejahteraan warga sekolah.

Salah satu bentuk unit produksi yang diterapkan di lingkungan SMK pada kelompok bisnis dan manajemen adalah business center. Business center bagi siswa SMK kelompok bisnis dan manajemen dapat berfungsi sebagai tempat untuk meningkatkan keterampilan di mana siswa dikondisikan seperti benar-benar terjun di lapangan pekerjaan. Melalui business center siswa dapat berlatih untuk menjual jasa maupun merencanakan pekerjaan, menghitung biaya pembuatan dan biaya penjualan, 
melaksanakan pekerjaan, mengontrol kualitas dan menjual barang hasil kerjanya.

Menurut Titik Komah Nurastuti selaku Penanggung jawab business centre sekaligus Kepala SMKN 7 Yogyakarta yang mengatakan, sesuai kebijakan Direktur Pembinaan SMK bahwa setiap SMK hendaknya memiliki unit usaha yang dapat dipergunakan sebagai tempat pembelajaran praktik siswa, khususnya dalam bidang kewirausahaan. Dan untuk SMK kelompok bisnis dan manajemen unit produksi/ jasa yang tepat adalah business center, yaitu unit usaha dalam bisnis ritel yang menyediakan berbagai macam barang kebutuhan sehari-hari bagi warga masyarakat. (http://kabarindonesia. com).

Faktanya, masih ada beberapa SMK di Kota Yogyakarta yang menggunakan metode konvensional, dimana pembelajaran kewirausahaan hanya sebatas teori atau pengatahuan saja tanpa mempraktikan secara langsung dalam kegiatan seharihari. Pemanfaatan sarana pembelajaran kewirausahaan melalui business center belum dilaksanakan secara maksimal dikarenakan keterbatasan tenaga, biaya/modal, sarana prasarana, dan kompetensi yang mendukung pemanfaatan business center sebagai sarana pembelajaran kewirausahaan.

Praktik Kerja Industri (Prakerin) merupakan program wajib yang harus diselenggarakan di SMK, yang mana upaya kewajiban tersebut dimaksudkan agar siswa secara mental dan keterampilan ketika lulus lebih siap bekerja dengan mengetahui gambaran dunia kerja secara nyata melalui kegiatan prakerin. Prakerin dalam dunia pendidikan kejuruan di Indonesia, merupakan penerapan dari kebijakan link and match yang berwawasan sumber daya manusia, masa depan, mutu, keunggulan, profesional, nilai tambah, dan efisiensi bagi pengelola pendidikan kejuruan. Dengan adanya kebijakan tersebut diharapkan mampu merubah paradigma pendidikan kejuruan yang semula supply driven menjadi demand driven dengan keterlibatan dunia kerja dalam pendidikan kejuruan.

Mutu lulusan SMK ditentukan oleh standar kompetensi kerja nasional Indonesia (SKKNI). Dengan adanya SKKNI ini memudahkan pemerintah mengembangkan program pembinaan SDM, membantu proses perekrutan oleh perusahaan, dan sebagai acuan untuk merumuskan sistem pengujian dan sertifikasi. Berdasarkan SKKNI ini mutu lulusan SMK diharapkan terampil di bidang kejuruan. Untuk menciptakan mutu lulusan yang baik maka SMK perlu memperbanyak praktik kerja di industri, jika praktik kerja di industri tidak ada atau sedikit maka mutu lulusan yang dihasilkan juga kurang bagus.

Berdasarkan hasil observasi terbatas yang dilakukan pada siswa kelas XII SMK Bopkri 1 Yogyakarta yang telah melaksanakan prakerin saat kelas XI ada beberapa kendala yang muncul selama prakerin berlangsung. Kendala-kendala yang muncul selama prakerin berlangsung antara lain: (1) bahwa di dalam pelaksanaan prakerin terkadang tidak sesuai dengan penempatan dengan bidang studi siswa; (2) antara materi pelajaran dengan tugas prakerin tidak sesuai; (3) monitoring yang dilakukan pembimbing selama proses prakerin berlangsung masih kurang. Sehingga apa yang menjadi tujuan prakerin belum tercapai secara maksimal.

Latar belakang keluarga siswa merupakan kondisi yang ada pada keluarga pada khususnya orang tua siswa yang dicerminkan dalam status sosial ekonomi (Sudjana, 2004: p.23). Status sosial ekonomi tersebut tercermin pada pekerjaan dan pendidikan orang tua, tempat tinggal atau kedudukan, pola asuh orang tua, cita-cita orang tua terhadap anak, serta penghasilan.

Menurut Lambing \& Kuehl (2000: p.37) kebanyakan dari keluarga yang wirausaha akhirnya membawa anak-anak ke dalam bisnis, mulai dari usia yang sangat dini, anakanak membantu dalam kegiatan perusahaan. Bisnis adalah bagian dari kehidupan mereka, seperti pasangan kewirausahaan lainnya, bisnis dioperasikan oleh anak-anaknya mulai dari toko-toko yang sangat kecil sampai perusahaan yang sangat besar.

Berdasarkan latar belakang penelitian yang telah dipaparkan di atas, maka perlu adanya penelitian untuk mengungkap "Pengaruh Pembelajaran Kewirausahaan melalui business center, Pengalaman Prakerin, dan Latar 
Tabel 1. Ciri-ciri dan Watak Kewirausahaan

\begin{tabular}{lll}
\hline No. & Ciri-Ciri & Watak \\
\hline 1 & Percaya diri dan optimis & $\begin{array}{l}\text { Memiliki kepercayaan diri yang kuat, ketidaktergantungan } \\
\text { terhadap orang lain, dan individualistis. }\end{array}$ \\
2 & $\begin{array}{l}\text { Berorientasi pada tugas dan } \\
\text { hasil }\end{array}$ & $\begin{array}{l}\text { Kebutuhan untuk berprestasi, berorientasi laba, mempunyai } \\
\text { dorongan yang kuat, energik, tekun dan tabah, tekad dan kerja } \\
\text { keras, serta inisiatif. }\end{array}$ \\
3 & $\begin{array}{l}\text { Berani mengambil resiko } \\
\text { dan menyukai tantangan }\end{array}$ & Mampu mengambil resiko yang wajar. \\
4 & Kepemimpinan & $\begin{array}{l}\text { Berjiwa kepemimpnan, mudah beradaptasi dengan orang lain, } \\
\text { dan terbuka terhadap saran serta kritik. } \\
\text { Inovatif, kreatif, dan fleksibel. } \\
\text { Memiliki visi dan perspektif terhadap masa depan. }\end{array}$ \\
6 & Keorisinilan &
\end{tabular}

Belakang Keluarga terhadap Kompetensi Berwirausaha Siswa SMK Negeri Kelompok Bisnis dan Manajemen di Kota Yogyakarta.

\section{Kompetensi Berwirausaha}

Wirausaha yang sukses pada umumnya adalah mereka yang memiliki kompetensi dalam ilmu pengetahuan, keterampilan dan kualitas individu yang meliputi sikap, motivasi, nilai serta tingkah laku yang diperlukan untuk melaksanakan pekerjaan/kegiatan. Hal tersebut diperkuat dengan pernyataan Suryana (2008: p.4) bahwa seorang wirausaha tidak akan berhasil apabila tidak memiliki pengetahuan, kemampuan, dan kemauan.

Kompetensi kewirausahaan merupakan karakteristik yang mendasar dari seseorang individu dalam menciptakan peluang atau kesempatan secara kreatif dan inovatif. Hal ini diperkuat oleh Dollinger (2003: p.5) bahwa kriteria seorang wirausaha yaitu kreatif dan inovatif, kemampuan mengumpulkan sumberdaya, mengubah peluang menjadi keuntungan dibawah kondisi resiko dan ketidakpastian.

Menurut Geofrey (1996: pp.5-6) karakteristik dan watak kewirausahaan sebagai yang dapat dilihat pada tabel 1 .

\section{Pembelajaran Kewirausahaan melalui Business Center}

Menurut Kamus Besar Bahasa Indonesia "bisnis" adalah usaha komersial dalam dunia perdagangan, bidang usaha, atau usaha dagang. Sejalan dengan itu bisnis dalam kamus lengkap bahasa Inggris-Indonesia (Wojowasito \& Poerwadarminta, 1980: p.20), business berarti pekerjaan, perusahaan, perdagangan, urusan, atau perkara. Sedangkan menurut Griffin dan Ebert (2006: p.4), bisnis (perusahaan) adalah organisasi yang menyediakan barang atau jasa untuk dijual dengan maksud mendapatkan laba. Dalam kamus lengkap Bahasa InggrisIndonesia (Wojowasito \& Poerwadarminta, 1980: p.23), center yang berarti pusat atau tengah. Jadi apabila disatukan pengertian business center yaitu pusat usaha atau pusat perusahaan. Business center merupakan tempat pusat usaha suatu organisasi yang menjual barang atau jasa kepada konsumen atau bisnis lainnya, untuk mendapatkan laba. business center salah satu bentuk dari unit produksi yang diterapkan di lingkungan SMK. Sehingga dalam penelitian ini yang dimaksud dengan business center yaitu wahana menumbuhkan dan mengembangkan jiwa wirausaha pada siswa SMK kelompok bisnis dan manajemen. Siswa melalui business center dapat berlatih untuk menjual jasa maupun merencanakan pekerjaan, menghitung biaya pembuatan dan biaya penjualan, melaksanakan pekerjaan, mengontrol kualitas dan menjual barang hasil kerjanya.

Adapun manfaat yang dapat diperoleh melalui pendidikan dan latihan melalui kegiatan unit produksi sekolah, menurut Pakpahan (Jaedun dkk, 2000: p.12) meliputi aspek edukatif, aspek ekonomi dan aspek sosial yang secara rinci dapat diuraikan sebagai berikut: 
Pertama aspek edukatif, yaitu (a) malatih sikap serta etos kerja yang positif bagi peserta didik serta melaksanakan pendidikan untuk berproduksi; (b) melatih mencari solusi yang menyeluruh tentang arti sebuah produksi; (c) melatih perkembangan yang seimbang pada perasaan yang berkaitan dengan fisik, emosi, mental, sikap, nilai normal estetika, baik untuk kepentingan sendiri maupun kepentingan masyarakat; (d) mendidik siswa untuk mengalami fase-fase kerja yang berhubungan dengan nilai ekonomi dan sosial dari berbagai fungsi; (e) mendidik dalam membentuk intergrasi yang kuat antara teori dan praktik dari berbagai macam jenis kerja; (f) pengembangan karakter anak yang meliputi kreativitas, motivasi positif dalam bekerja, disiplin, dan ketahanan mental dalam menghadapi tantangan; kedua aspek ekonomi, yaitu (a) memperkenalkan sejak dini aspek dan muatan ekonomi pada siswa SMK; (b) memupuk dan menumbuhkan jiwa wirausaha bagi siswa sehingga setelah mereka lulus tidak hanya berperan sebagai tenaga pencari kerja namun lebih dari itu dapat menciptakan dunia kerja mandiri; (c) perkembangan aktifitas kegiatan usaha dan bisnis di dunia kerja dapat diikuti oleh dunia pendidikan; (d) sebagai upaya baru untuk menemukan sarana pelatihan wirausaha di sekolah yang berorientasi pada dunia kerja; kedua aspek sosial, yaitu (a) pelaksanaan kegiatan unit produksi dapat dilandasi dengan semangat kebersamaan, tolong menolong, dan saling tukar pendapat; (b) terwujudnya komunikasi aktif secara langsung peserta didik dengan masyarakat; (c) semakin pendeknya masa transisi siswa dalam mengurangi kesenjangan antara tahap pendidikan dengan kerja produktif; (d) masyarakat industri dapat mengenal kondisi nyata secara sadar dan mengetahui secara tepat kemampuan siswa SMK dan menentukan pekerjaan yang sesuai dengan kemampuannya.

\section{Pengalaman Prakerin}

Praktik Kerja Industri adalah kegiatan yang bersifat wajib tempuh bagi siswa SMK yang merupakan bagian dari Program PSG. Dalam pedoman teknis pelaksanaan PSG pada SMK disebutkan bahwa "Praktik Kerja Industri (Prakerin) adalah praktik keahlian produktif yang dilaksanakan di industri atau perusahaan yang berbentuk kegiatan mengerjakan pekerjaan produksi atau jasa" (Depdikbud, 1997: p.2).

Prakerin bertujuan untuk meningkatkan lulusan yang memiliki pengetahuan, keterampilan, dan etos kerja yang sesuai dengan tuntutan lapangan kerja, meningkatkan disiplin kerja dan memberi penghargaan terhadap pengalaman kerja. Melalui Prakerin ini pengalaman dan wawasan siswa tentang dunia kerja akan bertambah sehingga nantinya mereka akan memiliki kesiapan kerja.

\section{Latar Belakang Keluarga}

Menurut Sudjana (2004: p.23) latar belakang keluarga siswa merupakan kondisi yang ada pada keluarga khususnya orang tua siswa yang dicerminkan dalam status ekonomi sosial. Latar belakang keluarga merupakan bagian dari pendidikan keluarga yang pada dasarnya juga bagian dari pendidikan informal yaitu proses pendidikan yang berlangsung sepanjang usia sehingga setiap memperoleh nilai, sikap, keterampilan, dan pengetahuan yang bersumber dari pengalaman hidup seharihari, pengaruh lingkungan termasuk didalamya pengaruh kehidupan keluarga, hubungan dengan tetangga, lingkungan pekerjaan.

Menurut Katz \& Green (2009: p.65) seorang anak yang mendapatkan pengalaman kerja kewirausahaan sejak dini, akan membantu mereka dalam mengembangkan keahlian, kompetensi dan kepercayaan diri, untuk menjadi pengusaha sukses. Lambing \& Kuehl (2000: p.37) mengatakan bahwa kebanyakan dari keluarga yang wirausaha akhirnya membawa anak-anak ke dalam bisnis, mulai dari usia yang sangat dini, anakanak membantu dalam kegiatan perusahaan. Bisnis adalah bagian dari kehidupan mereka, seperti pasangan kewirausahaan lainnya, bisnis dioperasikan oleh anak-anaknya mulai dari toko-toko yang sangat kecil sampai perusahaan yang sangat besar.

Latar belakang keluarga siswa adalah kondisi status sosial ekonomi yang dicerminkan dari pekerjaan dan pendidikan orang tua, tempat/tinggal atau kedudukan, pola asuh orang tua, cita-cita orang tua terhadap anak, serta penghasilan. 


\section{METODE PENELITIAN}

Penelitian ini merupakan penelitian asosiatif kausal. Penelitian ini dilaksanakan di SMK Negeri kelompok bisnis dan manajemen di Kota Yogyakarta, yaitu SMK Negeri 1 Yogyakarta dan SMK Negeri 7 Yogyakarta. Populasi berjumlah 493 orang dan sampel penelitian sebanyak 221 orang yang ditentukan dengan teknik random sampling.

Variabel dalam penelitian ini terdiri dari tiga variabel bebas. Variabel tersebut diberi simbol $\mathrm{X}_{1}, \mathrm{X}_{2}$, dan $\mathrm{X}_{3}$, yaitu Pembelajaran kewirausahaan melalui business center, Pengalaman prakerin, dan Latar belakang keluarga. Variabel terikat diberi simbol Y yaitu Kompetensi berwirausaha siswa SMK Negeri kelompok bisnis dan manajemen.

Teknik pengumpulan data dalam penelitian ini menggunakan angket yang berisi pertanyaan-pertanyaan yang diajukan kepada responden siswa kelas XI dengan mengacu pada skala likert yang bertujuan untuk memperoleh informasi data pengaruh pembelajaran kewirausahaan melalui business center, pengalaman prakerin, dan latar belakang keluarga terhadap kompetensi berwirausaha siswa SMK Negeri kelompok bisnis dan manajemen di Kota Yogyakarta dan dokumentasi yang bertujuan untuk melengkapi data yang telah direkam melalui angket.

Pengukuran kevalidan item meliputi validitas isi (content validity) dan validitas konstruk (construct validity). Validitas isi dilakukan dengan analisis rasional dengan cara membuat kisi-kisi dan mengkonsultasikan kepada dua penimbang ahli (expert judgement), yaitu Dr. Sukidjo sebagai ahli unit produksi dan Prof. Muhyadi sebagai ahli kewirausahaan. Setelah instrumen dinyatakan valid oleh penimbang ahli, kemudian angket diuji secara konstruk dengan cara diujicobakan kepada 30 siswa menggunakan analisis rumus korelasi product moment dan reliabilitas di analisis menggunakan Alfa Cronbach's. Teknik analisis data dalam penelitian ini menggunakan statistik deskriptif dan kriteria kecenderungan variabel.

Tabel 2. Kategori Kecenderungan Tiap Variabel

\begin{tabular}{cll}
\hline No & Interval Nilai & Kategori \\
\hline 1. & $\mathrm{M}+1,5 \mathrm{SD}$ Keatas & Sangat Baik \\
2. & $\mathrm{M} \mathrm{Sampai} \mathrm{M}+1,5 \mathrm{SD}$ & Baik \\
3. & $\mathrm{M}-1,5 \mathrm{SD}$ sampai $\mathrm{M}$ & Cukup \\
4. & $\mathrm{M}-1,5$ SD kebawah & Kurang \\
\hline
\end{tabular}

Ada empat uji prasyarat analisis dalam penelitian ini yaitu uji normalitas, uji linearitas, uji multikolinearitas, uji homoskedastisitas, dan uji autokorelasi. Pengujian hipotesis menggunakan analisis regresi ganda. Sebagai kriteria penerimaan dan penolakan digunakan tingkat signifikansi 5\%. Untuk mengetahui pengaruh masing-masing variabel terhadap variabel terikat digunkan analisis regresi sederhana dan untuk mengetahui besarnya pengaruh variabel bebas secara bersama-sama terhadap variabel terikat digunakan analisis regresi ganda. (Tabel 3)

Tabel 3. Distribusi Kecenderungan Kompetensi Bersirausaha, Pembelajaran Kewirausahaan melalui Business Center (X1), Pengalaman Prakerin (X2), dan Latar Belakang Keluarga (X3) Siswa SMK Negeri Kelompok Bisnis dan Manajemen di Kota Yogyakarta

\begin{tabular}{llcccccccc}
\hline \multirow{2}{*}{ No. Kategori } & \multicolumn{2}{c}{$\mathbf{Y}$} & \multicolumn{2}{c}{$\mathbf{X}_{\mathbf{1}}$} & \multicolumn{2}{c}{$\mathbf{X}_{\mathbf{2}}$} & \multicolumn{2}{c}{$\mathbf{X}_{\mathbf{3}}$} \\
\cline { 2 - 10 } & & $\mathbf{F}$ & $\mathbf{( \% )}$ & $\mathbf{F}$ & $\mathbf{( \% )}$ & $\mathbf{F}$ & $\mathbf{( \% )}$ & $\mathbf{F}$ & $\mathbf{( \% )}$ \\
\hline 1 & Sangat Baik & 15 & 6,79 & 13 & 5,88 & 13 & 5,88 & 15 & 6,79 \\
2 & Baik & 97 & 43,89 & 99 & 44,80 & 98 & 44,34 & 100 & 45,25 \\
3 & Cukup & 91 & 41,18 & 95 & 42,99 & 90 & 40,72 & 93 & 42,08 \\
4 & Kurang & 18 & 8,14 & 14 & 6,33 & 20 & 9,05 & 13 & 5,88 \\
\hline
\end{tabular}




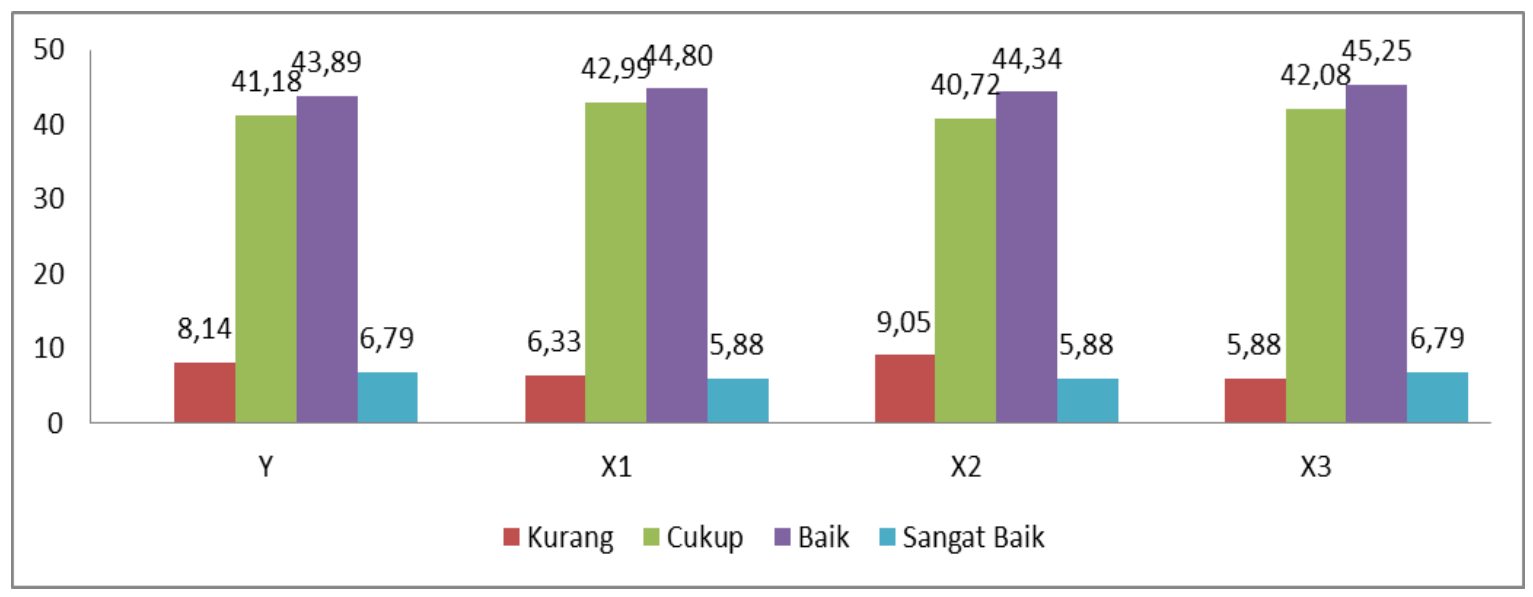

Gambar 1. Distribusi Kecenderungan Kompetensi Bersirausaha, Pembelajaran Kewirausahaan melalui Business Center $\left(X_{1}\right)$, Pengalaman Prakerin $\left(X_{2}\right)$, dan Latar Belakang Keluarga $\left(X_{3}\right)$ Siswa SMK Negeri Kelompok Bisnis dan Manajemen di Kota Yogyakarta

Tabel 4. Hasil Uji Hipotesis ke-1, ke-2, ke-3

\begin{tabular}{|c|c|c|c|c|c|c|}
\hline \multirow{2}{*}{\multicolumn{2}{|c|}{ Model }} & \multicolumn{2}{|c|}{$\begin{array}{l}\text { Unstandardized } \\
\text { Coefficients }\end{array}$} & \multirow{2}{*}{$\begin{array}{c}\begin{array}{c}\text { Standardized } \\
\text { Coefficients }\end{array} \\
\text { Beta } \\
\end{array}$} & \multirow[t]{2}{*}{$\mathbf{T}$} & \multirow[t]{2}{*}{ Sig. } \\
\hline & & $\boldsymbol{\beta}$ & Std. Error & & & \\
\hline \multirow[t]{2}{*}{1} & (Constant) & 80,211 & 3,764 & & 21,309 & 0,000 \\
\hline & $\begin{array}{l}\text { Pembelajaran Kewirausahan } \\
\text { melalui Business Center (X1) }\end{array}$ & 0,738 & 0,140 & 0,335 & 5,263 & 0,000 \\
\hline \multirow[t]{2}{*}{2} & (Constant) & 53,684 & 5,748 & & 9,339 & 0,000 \\
\hline & Pengalaman Prakerin (X2) & 1,144 & 0,142 & 0,478 & 8,055 & 0,000 \\
\hline \multirow[t]{2}{*}{3} & (Constant) & 48,863 & 4,974 & & 9,824 & 0,000 \\
\hline & Latar Belakang Keluarga (X3) & 1,308 & 0,127 & 0,571 & 10,293 & 0,000 \\
\hline \multicolumn{7}{|c|}{ a. Dependent Variable: Kompetensi Kewirausahaan (Y) } \\
\hline
\end{tabular}

\section{HASIL PENELITIAN DAN PEMBAHASAN}

Hasil perhitungan melalui statistik deskriptif pembelajaran kewirausahaan melalui business center, pengalaman prakerin, latar belakang keluarga dan kompetensi berwirausaha siswa SMK Negeri kelompok bisnis dan manajemen di Kota Yogyakarta

Dari tabel 3 variabel kompetensi berwirausaha menunjukkan kecenderungan untuk kategori sangat baik sebesar 6,79\%; baik sebesar 43,89\%; cukup 41,18\% dan kurang sebesar $8,14 \%$. Variabel pembelajaran kewirausahaan melalui business center menunjukkan kecenderungan untuk kategori sangat baik sebesar 5,88\%; baik sebesar 44,80\%; cukup 42,99\% dan kurang sebesar
6,33\%. Variabel pengalaman prakerin menunjukkan kecenderungan untuk kategori sangat baik sebesar 5,88\%; baik sebesar 44,34\%; cukup 40,72\% dan kurang sebesar $9,05 \%$. Variabel latar belakang keluarga menunjukkan kecenderungan untuk kategori sangat baik sebesar 6,79\%; baik sebesar 45,25\%; cukup 42,08\% dan kurang sebesar $5,88 \%$.

Dari Gambar 1 dapat disimpulkan bahwa variabel kompetensi berwirausaha dengan kategori baik sebesar $43,89 \%$. Untuk variabel pembelajaran kewirausahaan melalui business center dengan kategori baik sebesar 44,80\%. Sedangkan variabel pengalaman prakerin dengan kategori tinggi sebesar 44,34\%. Dan variabel latar belakang keluarga dengan kategori baik sebesar 45,25\%. 
Tabel 5. Hasil Uji Hipotesis ke-4

\begin{tabular}{llccccc}
\hline \multicolumn{7}{c}{ ANOVA $^{\mathbf{b}}$} \\
\hline Model & Sum of Squares & $\boldsymbol{d f}$ & Mean Square & F & Sig. \\
\hline 1 & Regression & 8758,504 & 3 & 2919,501 & 51,554 & $0,000^{\mathrm{a}}$ \\
& Residual & 12288,808 & 217 & 56,630 & & \\
& Total & 21047,312 & 220 & & & \\
\hline
\end{tabular}

a. Predictors: (Constant), Latar Belakang Keluarga (X3), Pembelajaran Kewirausahan melalui Business Center (X1), Pengalaman Prakerin (X2)

b. Dependent Variable: Kompetensi Kewirausahaan (Y)

Pengujian hipotesis dilakukan dengan menggunakan teknik analisis regresi sederhana untuk hipotesis pertama, kedua, dan ketiga. Sedangkan hipotesis keempat menggunakan teknik analisis regresi ganda menggunakan bantuan program komputer SPSS versi 16. Sebagai kriteria penerimaan dan penolakan, dalam pengujian ini digunakan tingkat signifikansi 5\%.

Berdasarkan tabel 4 dapat diketahui bahwa nilai sig $<5 \%$ untuk semua variabel, maka dapat disimpulkan bahwa:

\section{Uji Hipotesis Pertama}

Hipotesis pertama menyatakan bahwa pembelajaran kewirausahaan melalui business center berpengaruh positif dan signifikan terhadap kompetensi berwirausaha siswa SMK Negeri kelompok bisnis dan manajemen di Kota Yogyakarta.

Dari tabel 4 dapat diketahui bahwa nilai koefisien X1 bernilai positif sebesar 0,738 dan memiliki nilai sig 0,000 yang menunjukkan bahwa variabel pembelajaran kewirausahaan melalui business center memiliki hubungan yang positif dan siginifikan terhadap kompetensi berwirausaha siswa SMK Negeri kelompok bisnis dan manajemen di Kota Yogyakarta. Nilai koefisien $\left(\mathrm{X}_{1}\right)$ sebesar 0,738 juga memiliki arti, jika nilai pembelajaran kewirausahaan melalui business center meningkat satu poin maka nilai kompetensi berwirausaha akan meningkat sebesar 0,738 poin dengan asumsi bahwa $\mathrm{X}_{2}, \mathrm{X}_{3}$ adalah tetap. Sehingga hipotesis pertama diterima.

\section{Uji Hipotesis Kedua}

Hipotesis ketiga menyatakan bahwa pengalaman prakerin berpengaruh positif dan signifikan terhadap kompetensi berwirausaha siswa SMK Negeri kelompok bisnis dan manajemen di Kota Yogyakarta.

Dari tabel 4 dapat diketahui bahwa nilai koefisien $\mathrm{X}_{2}$ bernilai positif sebesar 1,144 dan memiliki nilai sig 0,000 yang menunjukkan bahwa variabel pengalaman prakerin memiliki hubungan yang positif dan siginifikan terhadap kompetensi berwirausaha siswa SMK Negeri kelompok bisnis dan manajemen di Kota Yogyakarta. Nilai koefisien $\left(\mathrm{X}_{2}\right)$ sebesar 1,144 juga memiliki arti, jika nilai pengalaman prakerin meningkat satu poin maka nilai kompetensi berwirausaha akan meningkat sebesar 1,144 poin dengan asumsi bahwa $\mathrm{X}_{1}, \mathrm{X}_{3}$ adalah tetap. Sehingga hipotesis kedua diterima.

\section{Uji Hipotesis Ketiga}

Hipotesis ketiga menyatakan bahwa latar belakang keluarga berpengaruh positif dan signifikan terhadap kompetensi berwirausaha siswa SMK Negeri kelompok bisnis dan manajemen di Kota Yogyakarta.

Dari tabel 4 dapat diketahui bahwa nilai koefisien $\mathrm{X}_{3}$ bernilai positif sebesar 1,308 dan memiliki nilai sig 0,000 yang menunjukkan bahwa variabel latar belakang keluarga memiliki hubungan yang positif dan siginifikan terhadap kompetensi berwirausaha siswa SMK Negeri kelompok bisnis dan manajemen di Kota Yogyakarta. Nilai koefisien $\left(\mathrm{X}_{3}\right)$ sebesar 1,308 juga memiliki arti, jika nilai latar belakang keluarga meningkat satu poin maka nilai kompetensi berwirausaha akan meningkat sebesar 1,308 poin dengan asumsi bahwa $\mathrm{X}_{1}, \mathrm{X}_{2}$ adalah tetap. Sehingga hipotesis ketiga diterima. 
Tabel 6. Koefisien Korelasi (R) dan Koefisien Determinasi $\left(\mathrm{R}^{2}\right)$

\begin{tabular}{ccccc}
\hline \multicolumn{5}{c}{ Model Summary } \\
\hline Model & $\mathbf{R}$ & R Square & Adjusted R Square & Std. Error of the Estimate \\
\hline 1 & $0,645^{\mathrm{a}}$ & 0,416 & 0,408 & 7,525 \\
\hline
\end{tabular}

a. Predictors: (Constant), Latar Belakang Keluarga (X3), Pembelajaran Kewirausahan melalui Business Center (X1), Pengalaman Prakerin (X2)

\section{Uji Hipotesis Keempat}

Hipotesis keempat menyatakan bahwa pembelajaran kewirausahaan melalui business center, pengalaman prakerin, dan latar belakang keluarga berpengaruh positif dan signifikan terhadap kompetensi berwirausaha siswa SMK Negeri kelompok bisnis dan manajemen di Kota Yogyakarta.

Dari tabel 5 dapat diketahui bahwa nilai $F$ sebesar 51,544 dan memiliki nilai sig 0,000 yang menunjukkan bahwa variabel pembelajaran kewirausahaan melalui business center, pengalaman prakerin, dan latar belakang keluarga memiliki hubungan yang positif dan siginifikan terhadap kompetensi berwirausaha siswa SMK Negeri kelompok bisnis dan manajemen di Kota Yogyakarta. Sehingga hipotesis keempat diterima.

Tabel 6 menunjukkan bahwa nilai koefisien korelasi (R) sebesar 0,645 dan harga koefisien determinasi $\left(R^{2}\right)$ sebesar 0,416 . Nilai tersebut berarti 41,6\% perubahan variabel kompetensi berwirausaha (Y) dapat diterangkan oleh pembelajaran kewirausahaan melalui business center $\left(\mathrm{X}_{1}\right)$, pengalaman prakerin $\left(\mathrm{X}_{2}\right)$ dan latar belakang keluarga $\left(\mathrm{X}_{3}\right)$ sedangkan 58,4\% dijelaskan variabel yang tidak diteliti dalam penelitian ini.

\section{Pengaruh pembelajaran kewirausahaan melalui business center terhadap kompetensi berwirausaha}

Berdasarkan analisis dengan SPSS versi 16 diperoleh nilai signifikansi 0,000 . Hal ini menunjukkan bahwa $\mathrm{p}<0,05$, sehingga dapat disimpulkan bahwa terdapat pengaruh positif dan signifikan pembelajaran kewirausahaan melalui business center terhadap kompetensi berwirausaha siswa SMK Negeri kelompok bisnis dan manajemen di Kota Yogyakarta. Dengan demikian dapat dikatakan semakin baik pembelajaran kewirausahaan melalui business center maka akan semakin tinggi pula kompetensi berwirausaha.

Besarnya sumbangan pembelajaran kewirausahaan melalui business center terhadap kompetensi berwirausaha ditunjukkan dengan hasil analisis regresi ganda dengan sumbangan efektif sebesar $7,35 \%$ dan sumbangan relatif sebesar $17,658 \%$, maka dapat dikatakan bahwa semakin baik pembelajaran kewirausahaan melalui business center maka akan semakin tinggi kompetensi berwirausaha dan sebaliknya.

Hasil tersebut didukung oleh penelitian Tuatul Mahfud (2012) tentang "Praksis Pembelajaran Kewirausahaan pada Unit Produksi Jasa Boga di SMK Negeri 6 Yogyakarta". Penelitian tersebut menunjukkan bahwa pembelajaran kewirausahaan sangat memerlukan pembelajaran berdasarkan pengalaman nyata (hands-on experiences) yaitu dengan cara melibatkan siswa langsung ke dalam kegiatan nyata berwirausaha, salah satunya yaitu melalui pembelajaran kewirausahaan di unit produksi.

Business center merupakan wahana menumbuhkan dan mengembangkan jiwa wirausaha pada siswa SMK kelompok bisnis dan manajemen. Siswa melalui business center dapat berlatih untuk menjual jasa maupun merencanakan pekerjaan, menghitung biaya pembuatan dan biaya penjualan, melaksanakan pekerjaan, mengontrol kualitas dan menjual barang hasil kerjanya.

Berdasarkan Pedoman Manajemen Pelaksanaan Unit Produksi (2007: p.7), penyelenggaraan Unit Produksi SMK mempunyai beberapa tujuan, enam diantaranya adalah: (1) memberikan kesempatan kepada siswa dan guru untuk mengerjakan praktik yang berorientasi pada pasar di lingkungan sekolah; 
(2) menumbuhkan dan mengembangkan jiwa wirausaha guru dan siswa pada sekolah menengah kejuruan; (3) membantu pendanaan untuk pemeliharaan, penambahan fasilitas dan biaya-biaya operasional pendidikan lainnya; (4) melatih untuk berani mengambil resiko dengan perhitungan yang matang; (5) meningkatkan kreativitas dan inovasi dikalangan siswa, guru dan manajemen sekolah; (6) unit produksi sekolah sebagai tempat magang bagi siswa praktik kerja industri yang tidak mendapat tempat di dunia kerja dan industri.

Berdasarkan penjelasan tersebut diatas, maka pembelajaran kewirausahaan melalui business center dapat dikatakan memberikan pengaruh positif dan signifikan terhadap kompetensi berwirausaha siswa SMK Negeri kelompok bisnis dan manajemen di Kota Yogyakarta. Pengaruh tersebut dilihat dari aspek edukatif, aspek ekonomi, dan aspek sosial yang mendukung tumbuhnya kompetensi berwirausaha pada diri siswa SMK Negeri kelompok bisnis dan manajemen di Kota Yogyakarta.

\section{Pengaruh pengalaman prakerin terhadap kompetensi beriwirausaha}

Berdasarkan analisis dengan SPSS versi 16 diperoleh nilai signifikansi sebesar 0,000 . Hal ini menunjukkan bahwa $\mathrm{p}<0,05$, sehingga dapat disimpulkan bahwa terdapat pengaruh positif dan signifikan pengalaman prakerin terhadap kompetensi berwirausaha siswa SMK Negeri kelompok bisnis dan manajemen di Kota Yogyakarta. Dengan demikian dapat dikatakan semakin baik pengalaman prakerin maka akan semakin tinggi pula kompetensi berwirausaha.

Besarnya sumbangan pengalaman prakerin terhadap kompetensi berwirausaha ditunjukkan dengan hasil analisis regresi ganda dengan sumbangan efektif sebesar $13,76 \%$ dan sumbangan relatif sebesar 33,066\%, maka dapat dikatakan bahwa semakin baik pengalaman prakerin maka akan semakin tinggi kompetensi berwirausaha dan sebaliknya.

HasiltersebutdidukungolehpenelitianJunil Adri (2013) tentang "Pengaruh pengalaman praktek kerja industri dan informasi dunia kerja terhadap minat berwirausaha". Penelitian tersebut menunjukkan bahwa secara simultan didapatkan besarnya pengaruh pengalaman praktek kerja indsutri dan informasi dunia kerja terhadap minat berwirausaha.

Prakerin adalah kegiatan praktik keahlian produktif bagi siswa SMK yang dilaksanakan di industri atau perusahaan yang sifatnya wajib ditempuh dengan tujuan untuk meningkatkan kecakapan siswa dalam bekerja sesuai dengan bidang keahliannya. Pengalaman prakerin bertujuan untuk meningkatkan lulusan yang memiliki pengetahuan, keterampilan, dan etos kerja yang sesuai dengan tuntutan lapangan kerja, meningkatkan disiplin kerja dan memberi penghargaan terhadap pengalaman kerja. Melalui Prakerin ini pengalaman dan wawasan siswa tentang dunia kerja akan bertambah sehingga nantinya mereka akan memiliki kesiapan kerja.

Berdasarkan penjelasan tersebut diatas, maka pengalaman prakerin memberikan pengaruh positif dan signifikan terhadap kompetensi berwirausaha siswa SMK Negeri kelompok bisnis dan manajemen di Kota Yogyakarta. Pengaruh positif pengalaman prakerin tersebut dilihat dari pengetahuan kerja, keterampilan kerja, sikap kerja yang benar, dan kreativitas kerja yang mendukung tumbuhnya kompetensi berwirausaha pada diri siswa SMK Negeri kelompok bisnis dan manajemen di Kota Yogyakarta.

\section{Pengaruh latar belakang keluarga terhadap kompetensi beriwirausaha}

Berdasarkan analisis dengan SPSS versi 16 diperoleh nilai signifikansi 0,000 . Hal ini menunjukkan bahwa $\mathrm{p}<0,05$, sehingga dapat disimpulkan bahwa terdapat pengaruh positif dan signifikan latar belakang keluarga terhadap kompetensi berwirausaha siswa SMK Negeri kelompok bisnis dan manajemen di Kota Yogyakarta. Dengan demikian dapat dikatakan semakin baik latar belakang keluarga maka akan semakin tinggi pula kompetensi berwirausaha.

Besarnya sumbangan latar belakang keluarga terhadap kompetensi berwirausaha ditunjukkan dengan hasil analisis regresi ganda dengan sumbangan efektif sebesar $20,50 \%$ dan sumbangan relatif sebesar 49,277\%, maka 
dapat dikatakan bahwa semakin baik latar belakang keluarga maka akan semakin tinggi kompetensi berwirausaha dan sebaliknya.

Hasil tersebut didukung oleh penelitian Eka Aprilianty (2012) tentang "Pengaruh kepribadian wirausaha, pengetahuan kewirausahaan, dan lingkungan terhadap minat berwirausaha siswa SMK". Penelitian tersebut menunjukkan bahwa lingkungan keluarga memberi pengaruh yang berarti terhadap minat berwirausaha siswa SMK.

Latar belakang keluarga siswa adalah kondisi status sosial ekonomi yang dicerminkan dari pekerjaan dan pendidikan orang tua, tempat/tinggal atau kedudukan, pola asuh orang tua, cita-cita orang tua terhadap anak, serta penghasilan. Dalam kaitannya pengaruh keluarga dalam pendidikan untuk membentuk kepribadian anak, Sudjana (2004: 63) mengatakan bahwa dalam perkembangannya keluarga-keluarga itu membentuk suatu pengelompokan atas dasar wilayah tempat tinggal dan keturunan. Pendapat tersebut senada dengan pendapat Routamaa bahwa anak-anak yang berasal dari keluarga wirausaha lebih positif dan realistis menjadi pengusaha.

Berdasarkan penjelasan tersebut diatas, maka latar belakang keluarga memberikan pengaruh positif dan signifikan terhadap kompetensi berwirausaha siswa SMK Negeri kelompok bisnis dan manajemen di Kota Yogyakarta. Pengaruh positif latar belakang keluarga tersebut dilihat dari pekerjaan orang tua, pendidikan orang tua, status sosial ekonomi orang tua, pandangan orang tua tentang pendidikan, dan pola atau gaya orang tua mendidik anak yang mendukung tumbuhnya kompetensi berwirausaha pada diri siswa SMK Negeri kelompok bisnis dan manajemen di Kota Yogyakarta.

\section{Pengaruh pembelajaran kewirausahaan, pengalaman prakerin, dan latar belakang keluarga terhadap kompetensi beriwirausaha}

Berdasarkan hasil analisis dengan bantuan program SPSS versi 16 diperoleh nilai signifikansi sebesar 0,000 . Hal ini menunjukkan bahwa $\mathrm{p}<0,05$, sehingga dapat disimpulkan bahwa terdapat pengaruh positif dan signifikan pembelajaran kewirausahaan melalui business center, pengalaman prakerin, dan latar belakang keluarga secara bersamasama terhadap kompetensi berwirausaha. Melalui analisis regresi tiga prediktor dapat diketahui pula sumbangan efektif dari pembelajaran kewirausahaan melalui business center, pengalaman prakerin, dan latar belakang keluarga secara bersama-sama terhadap kompetensi berwirausaha sebesar $41,6 \%$ sedangkan $58,4 \%$ berasal dari variabel lain yang tidak diteliti dalam penelitian ini.

Hasil tersebut didukung oleh penelitian Tuatul Mahfud (2012) tentang "Praksis Pembelajaran Kewirausahaan pada Unit Produksi Jasa Boga di SMK Negeri 6 Yogyakarta", Junil Adri (2013) tentang "Pengaruh pengalaman praktek kerja industri dan informasi dunia kerja terhadap minat berwirausaha", Eka Aprilianty (2012) tentang "Pengaruh kepribadian wirausaha, pengetahuan kewirausahaan, dan lingkungan terhadap minat berwirausaha siswa SMK". Penelitian tersebut mendukung bahwa secara bersama-sama dapat berpengaruh pembelajaran kewirausahaan melalui business center, pengalaman prakerin, dan latar belakang keluarga memberikan pengaruh yang positif terhadap peningkatan kompetensi berwirausaha pada siswa SMK kelompok bisnis dan manajemen di Kota Yogyakarta.

\section{SIMPULAN DAN SARAN}

\section{Simpulan}

Berdasarkan hasil penelitian dan pembahasannya, maka dapat ditarik kesimpulan sebagai berikut: (1) pembelajaran kewirausahaan melalui business center berpengaruh positif dan signifikan terhadap kompetensi berwirausaha siswa SMK Negeri kelompok bisnis dan manajemen di Kota Yogyakarta. Hasil analisis ditemukan nilai sigifikansi $0,000<0,05$, maka Ho ditolak yang artinya variabel pembelajaran kewirausahaan melalui business center mempunyai pengaruh positif dan signifikan terhadap kompetensi berwirausaha jika variabel pengalaman prakerin $\left(\mathrm{X}_{2}\right)$ dan latar belakang keluarga $\left(\mathrm{X}_{3}\right)$ dikendalikan/dikontrol; (2) pengalaman 
prakerin berpengaruh positif dan signifikan terhadap kompetensi berwirausaha siswa SMK Negeri kelompok bisnis dan manajemen di Kota Yogyakarta. Hasil analisis ditemukan nilai signifikansi $0,000<0,05$, maka Ho ditolak yang artinya variabel pengalaman prakerin mempunyai pengaruh positif dan signifikan terhadap kompetensi berwirausaha jika variabel pembelajaran kewirausahaan melalui business center $\left(\mathrm{X}_{1}\right)$ dan latar belakang keluarga $\left(\mathrm{X}_{3}\right)$ dikendalikan/dikontrol; (3) latar belakang keluarga berpengaruh positif dan signifikan terhadap kompetensi berwirausaha siswa SMK Negeri kelompok bisnis dan manajemen di Kota Yogyakarta. Ditemukan nilai signifikansi $0,000<0,05$, maka $\mathrm{Ho}$ ditolak yang artinya variabel latar belakang keluarga mempunyai pengaruh positif dan signifikan terhadap kompetensi berwirausaha jika variabel pembelajaran kewirausahaan melalui business center $\left(\mathrm{X}_{1}\right)$ dan pengalaman prakerin $\left(\mathrm{X}_{2}\right)$ dikendalikan/dikontrol; (4) pembelajaran kewirausahaan melalui business center, pengalaman prakerin, latar belakang keluarga secara besama-sama berpengaruh positif dan signifikan terhadap kompetensi berwirausaha siswa SMK Negeri kelompok bisnis dan manajemen di Kota Yogyakarta. Hasil analisis regresi ganda ditemukan nilai signifikansi sebesar 0,000 . Oleh karena nilai signifikansi $<0,05$ maka Ho ditolak yang artinya variabel pembelajaran kewirausahaan melalui business center $\left(\mathrm{X}_{1}\right)$, pengalaman prakerin $\left(\mathrm{X}_{2}\right)$, dan latar belakang keluarga $\left(\mathrm{X}_{3}\right)$ secara bersama-sama mempunyai pengaruh positif dan signifikan terhadap kompetensi berwirausaha. Nilai sumbangan efektif sebesar $41,6 \%$, artinya besarnya kontribusi/sumbangan pembelajaran kewirausahaan melalui business center, pengalaman prakerin dan latar belakang keluarga terhadap kompetensi berwirausaha adalah sebesar $41,6 \%$, sisanya $(58,4 \%)$ berasal dari variabel lain.

\section{Saran}

Berdasarkan kesimpulan yang telah diuraikan sebelumnya, maka penelitian ini memiliki saran sebagai berikut :

Bagi Dinas Pendidikan Kota Yogyakarta

Bagi dinas pendidikan diharapkan menjalin kerjasama dengan dunia usaha dan dunia industri (DU/DI) untuk menjadi sponsor dan mendukung pengembangan praktik kerja industri (prakerin) yang membutuhkan sponsor sebagai partner untuk memberikan pengalaman belajar secara nyata bagi siswa.

Bagi SMK, yaitu: bagi pihak sekolah diharapkan untuk menciptakan lingkungan dan suasana yang mendukung pembelajaran kewirausahaan. Ketersediaan waktu dan tempat hendaknya mendapat kelonggaran agara pembelajaran kewirausahaan melalui business center bisa berjalan dengan baik. Selain itu pihak sekolah diharapkan untuk selalu mengikutsertakan para guru dalam pendampingan pembelajaran kewirausahaan melalui business cnter serta memberikan fasilitas, sarana prasarana untuk kelancaran pembelajaran kewirausahaan melalui business center. Dukungan sekolah dalam bentuk spiritual dan motivasi juga dibutuhkan oleh siswa dalam menjalankan pembelajaran kewirausahaan melalui business center.

Bagi guru, yaitu: (1) guru diharapkan dapat melatih siswa untuk berwirausaha agar setelah menyelesaikan sekolah tidak tergantung pada penyaluran kerja yang ada di sekolah. Oleh karena itu, hendaknya kreatif dalam memfasilitasi siswa belajar kewirausahaan baik secara teori maupun praktik; (2) bagi guru, khususnya guru mata pelajaran kewirausahaan, hendaknya menggunakan pembelajaran kewirausahaan melalui business center dalam proses pembelajaran agar siswa lebih aktif dalam pembelajaran; (3) guru diharapkan untuk berperan aktif mendampingi dan memfasilitasi siswa dalam pelaksanaan pembelajaran kewirausahaan melalui business center agar siswa tidak jenuh dalam belajar, sehingga meningkatkan pengetahuan dan kompetensi wirausaha siswa.

Bagi siswa, yaitu: (1) para siswa diharapkan dapat berpartisipasi aktif dalam proses pembelajaran kewirausahaan dan prakerin agar dapat memperoleh manfaat berupa pengetahuan, pemahaman, keterampilan dan kompetensi wirausaha yang lebih baik; (2) setelah selesai mengikuti pembelajaran kewirausahaan melalui business center dan prakerin, diharapkan siswa SMK mempunyai pemikiran dan pandangan untuk melanjutkan 
usaha agar mampu membuka lapangan usaha secara mandiri.

Bagi penelitian selanjutnya, yaitu: (1) dalam penelitian ini, kompetensi berwirausaha dipengaruhi oleh pembelajaran kewirausahaan melalui business center, pengalaman prakerin, dan latar belakang keluarga. Untuk pengembangan penelitian selanjutnya dapat dilakukan dengan berbagai macam metode yang dapat digunakan agar siswa mempunyai kompetensi wirausaha yang baik dan factor-faktor lain yang mendungkung tumbuhnya kompetensi berwirausaha pada diri siswa SMK; (2) skala pengukuran untuk kompetensi wirausaha seharusnya tidak hanya menggunakan kuesioner (angket) saja, tetapi juga dapat perlu untuk dilakukan pengamatan untuk skala sikap dan keterampilan yang dimiliki oleh siswa.

\section{DAFTAR PUSTAKA}

Jaidun, Amat Dkk, (2000). Hibah penelitian program due-dike, manajemen up jurusan bangunan. Laporan Penelitian Yogyakarta: Lemlit UNY tidak diterbitkan.

Wijayanto, Bayu. (6 Desember 2008). Walikota resmikan business centre SMK N 7 Yogyakarta. Diambil pada tanggal 1 September 2013, dari http:// www.kabarindonesia.com/berita. php?pil=26\&dn=20081206131859

Depdikbud. (1997). Penyusunan kurikulum pendidikan sistem ganda. Jakarta: Depdikbud.

Depdiknas. (2003). Undang-undang Republik Indonesia nomor 20 tahun 2003, tentang sistem pendidikan nasional.

Depdiknas. (2008). Kamus besar bahasa Indonesia. Diambil pada tanggal 20 September 2013, dari http://bahasa. kemdiknas.go.id/kbbi/index.php

Dirjen Peningkatan Mutu Tendik. (2007). Pedoman manajemen unit produksi dan jasa sebagai sumber belajar siswa dan penggalian pendanaan pendidikan.
Dollinger, M. J. (2003). Entrepreneurship: strategis and resources $\left(3^{r d} e d\right)$. New Jersey: Prentice Hall.

Aprilianty, Eka. (2012). Pengaruh kepribadian wirausaha, pengetahuan kewirausahaan, dan lingkungan terhadap minat berwirausaha. Tesis. Yogyakarta: UNY.

Lia, Erika. (19 September 2013). Jumlah pengusaha di Indonesia hanya 1,25\%. Diambi pada tanggal 19 September 2013, dari http://ekbis.sindonews.com/ $\mathrm{read} / 785269 / 34 /$ jumlah-pengusaha-diindonesia-hanya-1-25

Geoffrey, G. M, et. Al. (1996). Kewirausahaan teori dan praktek. Jakarta: PT. Pustaka inaman Presindo.

Hisrich, R.D., \& Peters, M.P. (2002). Entrepreneurship. 5thed. New York: The McGraw Hill.

Adri, Junil. (2013). Pengaruh pengalaman praktek kerja industri dan informasi dunia kerja terhadap minat berwirausaha. Tesis. Yogyakarta: UNY

Katz, J. A., \& Green, R.P. (2009). Entrepreneurial small business. New York: Mc Graw-Hill.

Kementerian Koperasi dan UMKM RI. (2012). Modul seri kewirausahaan: prospek dan peluang berwirausahan. Di unduh pada tanggal 23 September 2013, dari http:// www.langkahwirausaha.com/uploads/ MODUL_1 -_PROSPEK_DAN PELUANG_BERWIRAUSA $\overline{\text { BHA_\% }}$ 28REVISI_2\%29.pdf

Lambing. P., \& Kuehl, C. R. (2000). Entrepreneurship. Upper Saddle River: Prentice Hall

Prlm. (1 September 2013). Kewirausahaan Indonesia tertinggal. Diambil pada tanggal 1 September 2013, dari http:// www.pikiran-rakyat.com/node/248888

Griffin, R. W., Ronald J. E. (2006). Bisnis. Jakarta: Erlangga. 
Sugiyono. (2007). Statistika untuk penelitian. Bandung: Alfabeta.

Sugiyono. (2009). Metode penelitian pendidikan. Bandung: CV Alfabeta.

Sudira, Putu. (2012). Filosofi dan teori pendidikan vokasi dan kejuruan. Yogyakarta. UNY Press.

Sudjana. (2004). Pendidikan nonformal, wawasan sejarah perkembangan dan filsafat teori pendukung asas. Bandung: Falah Production.

Sudjana. (2010). Penilaian hasil proses belajar mengajar. (Cet. XV). Bandung: PT. Ramaja Rosdakarya.
Suryana. (2008). Kewirausahaan: pedoman praksis, kiat dan proses menuju sukses. Jakarta: Salemba Empat.

Mahfud, Tuatul. (2012). Praksis pembelajaran kewirausahaan pada unit produksi jasa boga di SMK negeri 6 yogyakarta. Tesis. Yogyakarta: UNY.

Universitas Negeri Yogyakarta. (2013). Pedoman penulisan tesis dan disertasi. Yogyakarta: PPs. UNY.

Wojowasito \& Poerwadarminta. (1980). Kamus lengkap Inggri-Indonesia. Bandung: Penerbit Hasta. 